\title{
Anxiogenic Effect of Cholecystokinin in the Dorsal Periaqueductal Gray
}

\author{
Cristina Ferreira Netto' and Francisco Silveira Guimarães*,2 \\ 'Laboratory of Psychobiology, FFCLRP, Ribeirão Preto, SP, Brazil; ${ }^{2}$ Department of Pharmacology, FMRP, Ribeirão Preto, SP, Brazil
}

\begin{abstract}
Systemic administration of cholecystokinin (CCK) fragments produces anxiogenic effects. The dorsal periaqueductal gray (dPAG) has been related to anxiety and panic reactions. The objective of this study was to investigate a possible anxiogenic effect of CCK- 8 microinjected into the dPAG. At 10 min after the last microinjection $(0.5 \mu l)$ into the dPAG male Wistar rats $(N=7-17)$ were tested in the elevated plus-maze, an animal model of anxiety. The following treatments were tested alone or in combination: sulfated CCK-8 (CCK-8s, 0.5-I $\mu \mathrm{g}$ ), PD 135, 158 ( $\mathrm{N}$-methyl-D-glucamine, $0.1 \mu \mathrm{g}$ ), a CCK-2 receptor antagonist, lorglumide $(0.1-0.3 \mu \mathrm{g})$, a CCK-I receptor antagonist. In addition, Fos immunohistochemistry was performed in rats $(n=3-4)$ treated with CCK-8s $(I \mu g)$ alone or in combination with PD I35, I58 (0.I $\mu \mathrm{g})$. CCK-8s produced anxiogenic-like effect, decreasing the percentage of time spent in open arm (saline $=30.3 \pm 6.6$, CCK $0.5 \mu \mathrm{g}=15.2 \pm$ ।.8; CCK I $\mu \mathrm{g}=14.6 \pm 2.1$ ). This effect was prevented by pretreatment with PD I35, I58, but not by lorglumide. CCK-8s injected into the dPAG induced Fos immunoreactivity in several brain areas related to defensive behavior, including the PAG, median, and dorsal raphe nuclei, superior colliculus, lateral septal nuclei, medial hypothalamus, and medial amygdala. This effect was also prevented by pretreatment with PD 135, I58. These results suggest that CCK-8s, acting on CCK-2 receptors, may modulate anxiety reactions in the dPAG.

Neuropsychopharmacology (2004) 29, I0I - 107, advance online publication, 29 October 2003; doi: I 0. I038/sj.npp. I 300334
\end{abstract}

Keywords: elevated plus-maze; CCK receptors; anxiety; Fos

\section{INTRODUCTION}

The midbrain dorsal periaqueductal gray (dPAG) matter is a key structure in the control of defensive behaviors (Behbehani, 1995). Several neurotransmitters have been shown to modulate neuronal activity in this region. For example, injection into the dPAG of drugs that facilitate GABAergic or serotonergic neurotransmission attenuates the aversive consequences of dPAG electrical stimulation and produces anxiolytic-like effects in the elevated plus-maze (EPM, Russo et al, 1993; Lovick, 2000). Similar effects were produced by glutamate antagonists (Guimarães et al, 1991).

Neuropeptides may also modulate defensive responses in the PAG (Behbehani, 1995). Cholecystokinin (CCK) is one of the most widespread peptide system in the brain. It is involved in many brain physiological or pathological conditions, including anxiety, panic, and depression (Guimarães et al, 1992; Hernandez-Gomez et al, 2002; Bradwejn et al, 1992, 1994; Rehfeld, 2000). CCK-immunoreactive fibers and a high concentration of CCK exist in the PAG (De

\footnotetext{
*Correspondence: Dr FS Guimarães, Department of Pharmacology, FMRP, Campus USP, I4049-900, Ribeirão Preto, SP, Brazil, Tel: + 55 I6 6023209, Fax: + 55 16 6332301, E-mail: fsguimar@fmrp.usp.br Received 30 June 2003; revised 12 September 2003; accepted 16 September 2003

Online publication: 19 September 2003 at http://www.acnp.org/ citations/Npp09190303288/default.pdf
}

Belleroche et al, 1990; Liu et al, 1994). Aversive stimuli such as restraint, social isolation, or exposure to the smell of a predator increase CCK levels and/or expression in the PAG and limbic regions such as the amygdala and hippocampus (Del Bel and Guimarães, 1997; Pavlasevic et al, 1993; Rosen et al, 1992). Systemic injection of CCK agonists or antagonists produces anxiogenic or anxiolytic effects, respectively (Griebel et al, 1997, Hernandez-Gomez et al, 2002). These effects may involve the dPAG since systemic administration of anxiogenic compounds, including the CCK analogue BOCCCK4, induces Fos immunoreactivity in the dPAG (Singewald and Sharp, 2000). Moreover, intra-dPAG injection of CCK-8s was reported to be anxiogenic in the EPM (Guimarães et al, 1992). The objective of the present work was to investigate the anxiogenic effects of CCK in the dPAG. We tested the hypothesis that these effects are mediated by CCK-2 receptors. Moreover, we used the expression of the immediate-early gene Fos as a marker of neuron functional activity (Morgan and Curran, 1995) to detect brain areas stimulated by CCK-8s injection into the dPAG.

\section{MATERIALS AND METHODS}

\section{Subjects}

Male Wistar rats (200-250 g) were housed in pairs with free access to food and water in a temperature controlled room 
$\left(23 \pm 1^{\circ} \mathrm{C}\right)$ with a $12 \mathrm{~h}$ light, $12 \mathrm{~h}$ dark cycle (lights on at 0600). The experiments were carried out according to the Brazilian Society of Neuroscience and Behavior guidelines for care and use of Laboratory animals, and all efforts were made to minimize animal suffering.

\section{Elevated plus-maze}

The wood plus-shaped maze consisted of two open and two enclosed arms of equal length and width $(50 \times 10 \mathrm{~cm})$. The enclosed arms had $40 \mathrm{~cm}$ high wooden walls while a $1-\mathrm{cm}$ high edge made of Plexiglas surrounded the open arms to prevent falls.

The experiment was carried out in a sound attenuated, temperature-controlled $\left(23 \pm 1^{\circ} \mathrm{C}\right)$ room. The environment was illuminated by two $40 \mathrm{~W}$ fluorescent lights placed $1.3 \mathrm{~m}$ away from the EPM.

\section{Drugs}

All drugs were dissolved in sterile isotonic saline. The doses of sulfated CCK octapeptide (CCK-8s, RBI, USA) were chosen based on previous work by our group (Guimarães et al, 1992). The doses employed for $N$-methyl-D-glucamine (PD 135,158, RBI, USA) and lorglumide (RBI, USA), potent and selective CCK-2 and CCK-1 receptor antagonists, respectively (Herranz, 2003), were based on the literature (Costall et al, 1991, Griebel et al, 1997).

\section{Surgery}

Rats were anesthetized with 2.5\%. 2,2,2,-tribromoethanol $(10 \mathrm{ml} / \mathrm{kg}$, i.p. $)$ and fixed in a stereotaxic frame to implant a stainless-steel guide cannula $(0.7 \mathrm{~mm}, \mathrm{OD})$ into the $\mathrm{dPAG}$ (coordinates: AP: interaural $1.2 \mathrm{~mm}$, lateral: $1.9 \mathrm{~mm}$ at an angle of $16^{\circ}$ with the sagital plane). The guide cannula was introduced until its tip was $4.1 \mathrm{~mm}$ below the surface of the skull. The cannula was attached to the bone with stainlesssteel screws and acrylic cement. An obturator inside the guide cannulae prevented obstruction.

\section{Behavioral Studies}

Intracerebral injections were performed with a thin dental needle $(0.3 \mathrm{~mm}, \mathrm{OD})$ introduced through the guide cannula until its tip was $1 \mathrm{~mm}$ below the cannula end. A volume of $0.5 \mu \mathrm{l}$ was injected during $30 \mathrm{~s}$ using an infusion pump (KdScientific). The movement of an air bubble inside the PE 10 polyethylene tubing connecting the pump with the dental needle confirmed drug flow. At $10 \mathrm{~min}$ after the last microinjection the rat was placed in the centre of the plus-maze facing an enclosed arm. The session was videotaped and analyzed later with the help of Ethovision (Version 1.9, Noldus, Netherlands) software. The program detects the position of the animal in the maze and calculates the number of entries and time spent in open and enclosed arms. For these calculations a 6-cm large 'exclusion' zone was added between the center of the maze and each arm so that most of the animal's body should be in the open or enclosed arm to an entry to be registered. Each session lasted for $5 \mathrm{~min}$ and after each trial the maze was cleaned with an alcohol solution.
The experiments took place 7 days after the surgery. Three experiments were performed.

Experiment 1: Animals received intra-dPAG injection of saline $(n=9)$, CCK-8s $0.5 \mu \mathrm{g}(n=11)$, or $1 \mu \mathrm{g}(n=12)$, and were tested in the EPM 10 min later.

Experiment 2: The animals received a first microinjection into the dPAG of either saline $(n=11-12)$ or PD 135,158 (0.1 $\mathrm{g}, \quad n=11-14)$ followed, $5 \mathrm{~min}$ later, by a second microinjection of saline or CCK-8s $1 \mu \mathrm{g}$.

Experiment 3: It was similar to experiment 3, except that the animals were pretreated with saline $(n=14-17)$ or lorglumide $(0.1$ or $0.3 \mu \mathrm{g}, n=7-14)$ before saline or CCK-8s administration.

\section{Histological Control}

After the behavioral tests the animals were killed under deep anesthesia and their brains perfused through the left ventricle of the heart with isotonic saline followed by $10 \%$ formalin solution. After that $0.2 \mu \mathrm{l}$ of Fast green (1\%) was injected through the guide cannula and the brains were removed. Following a minimum period of 3 days immersed in a $10 \%$ formalin solution, frozen sections of $50 \mu \mathrm{m}$ were obtained in a cryostat (Cryocut, 1800). The injection sites were localized in diagrams from the Paxinos and Watson's (1987) rat brain atlas. No distinction was made between dorsomedial and dorsolateral PAG. Animals receiving microinjections outside the $\mathrm{dPAG}$ were excluded from analysis. Since most of these animals received their microinjection into the superior colliculus, they were compared in a separated analysis.

\section{Fos Immunohistochemistry}

Two experiments were performed. In experiment 1 animals received microinjection into the $\mathrm{dPAG}$ of saline $(0.5 \mu \mathrm{l}$, $n=4)$, CCK-8s $(1 \mu \mathrm{g}, n=4)$ or were left undisturbed in their home cages (naive, $n=3$ ). In the second experiment animals ( $n=2-4$ /group) received a first microinjection of saline $(0.5 \mu \mathrm{l})$ or PD $135,158(0.1 \mu \mathrm{g})$ followed, 5 min later, by a second microinjection of saline or CCK-8s $(1 \mu \mathrm{g})$. At $2 \mathrm{~h}$ after the last injection the animals were anesthetized with an overdose of urethane and perfused transcardially with saline followed by $4 \%$ paraformaldehyde in $0.1 \mathrm{M}$ phosphate buffer $(\mathrm{pH}=7.4)$. Brains were removed and postfixed over $2 \mathrm{~h}$ in paraformaldehyde and stored for at least $48 \mathrm{~h}$ in $30 \%$ sucrose for cryoprotection. Transverse sections $(40 \mu \mathrm{m})$ were obtained in a cryostat and processed for Fos immunohistochemistry (Silveira et al, 1994). Tissue sections were washed and incubated overnight at room temperature with rabbit IgG (1/10.000 into PBS, sc-52, Santa Cruz), which was raised against an amino-acid sequence of the $\mathrm{N}$ terminal region of the peptide and specifically recognizes Fos. Sections were then processed by the avidin-biotin immunoperoxidase method (Vectastain ABC kit, Vector Lab, Burlingame, CA, USA). Fos immunoreactivity (FIr) was revealed by the addition of the chromogen diaminobenzidin (Sigma) and visualized as a brown reaction product inside neuronal nuclei.

The number of Fos-positive nuclei was counted from a fixed area in regions selected from previous studies (De Oliveira et al, 2000, Lino-de-Oliveira et al, 2001) using a 
computerized image analysis system (Image-Pro Plus). For bilateral structures the mean value between each side was analyzed. The system was calibrated to ignore background staining. Darker objects with areas between 10 and $80 \mu \mathrm{m}^{2}$ were identified as Fos-positive neurons as described by Lino-de-Oliveira et al (2001). The analyzed regions and their respective areas were as follows: frontal cortex (AP: $0.70 \mathrm{~mm}$ from bregma, Paxinos and Watson, 1987, area: $0.3 \times 10^{6} \mu \mathrm{m}^{2}$ ), cingulate cortex (AP: $0.70 \mathrm{~mm}$, area: $0.3 \times 10^{6} \mu \mathrm{m}^{2}$ ), basolateral amygdala (BlAmyg, AP: $-2.80 \mathrm{~mm}$, area: $0.28 \times 10^{6} \mu \mathrm{m}^{2}$ ), medial amygdala (MeAmyg, AP: $-2.30 \mathrm{~mm}$, area: $0.28 \times 10^{6} \mu \mathrm{m}^{2}$ ), central nucleus of the amygdala (CeAmyg, AP: $-2.56 \mathrm{~mm}$, area: $0.28 \times 10^{6} \mu \mathrm{m}^{2}$ ), lateral division of the bed nucleus of the stria terminalis, ventral part (BNSTv, AP: $-0.26 \mathrm{~mm}$, area: $0.14 \times 10^{6} \mu \mathrm{m}^{2}$ ), medial division of the bed nucleus of the stria terminalis (BNSTm, AP: $-0.26 \mathrm{~mm}$, area: $0.25 \times 10^{6} \mu \mathrm{m}^{2}$ ), lateral septal nucleus, dorsal, (LSd, AP: $0.20 \mathrm{~mm}$, area: $0.25 \times 10^{6} \mu \mathrm{m}^{2}$ ), intermediate (LSi, AP: $0.20 \mathrm{~mm}$, area: $0.3 \times 10^{6} \mu \mathrm{m}^{2}$ ) and ventral (LSv, AP: $0.20 \mathrm{~mm}$, area: $0.3 \times 10^{6} \mu \mathrm{m}^{2}$ ) parts, CA1 (AP: -3.14 to $-3.30 \mathrm{~mm}$, area: $0.20 \times 10^{6} \mathrm{~mm}^{2}$ ), CA2 (AP: -3.14 to $-3.30 \mathrm{~mm}$, area: $0.16 \times 10^{6} \mathrm{~mm}^{2}$ ), CA3 (AP: -3.14 to $-3.30 \mathrm{~mm}$, area: $0.20 \times 10^{6} \mathrm{~mm}^{2}$ ), anterior hypothalamic area (AntH, AP: $-1.80 \mathrm{~mm}$, area: $0.28 \times 10^{6} \mathrm{~mm}^{2}$ ), dorsomedial hypothalamic nucleus $(\mathrm{DmH}, \mathrm{AP}:-3.14 \mathrm{~mm}$, area: $0.30 \times 10^{6} \mathrm{~mm}^{2}$ ), lateral hypothalamus (LH, AP: $-1.80 \mathrm{~mm}$, area: $0.28 \times 10^{6} \mathrm{~mm}^{2}$ ), paraventricular nucleus of the hypothalamus, magnocellular (PVNm, AP: $-1.80 \mathrm{~mm}$, area: $0.43 \times 10^{6} \mu \mathrm{m}^{2}$ ) and parvocellular (PVNp, AP: $-1.80 \mathrm{~mm}$, area: $\left.0.12 \times 10^{6} \mu \mathrm{m}^{2}\right)$ parts, paraventricular nucleus of the thalamus (PVT, AP: $-1.80 \mathrm{~mm}$, area: $.0 .2 \times 10^{6} \mu \mathrm{m}^{2}$ ), dorsolateral periaqueductal gray (dlPAG, AP: -6.80 to $-7.30 \mathrm{~mm}$, area: $0.3 \times 10^{6} \mu \mathrm{m}^{2}$ ), lateral periaqueductal gray (lPAG, AP: -6.80 to $-7.30 \mathrm{~mm}$, area: $0.3 \times 10^{6} \mu \mathrm{m}^{2}$ ), dorsomedial periaqueductal gray (dmPAG, AP: -6.80 to $-7.30 \mathrm{~mm}$, area: $0.3 \times 10^{6} \mu \mathrm{m}^{2}$ ), median raphe nucleus (MRN, AP: $-7.80 \mathrm{~mm}$, area: $0.3 \times 10^{6} \mu \mathrm{m}^{2}$ ), dorsal raphe nucleus (DRN, AP: $-7.30 \mathrm{~mm}$, area: $0.3 \times 10^{6} \mu \mathrm{m}^{2}$ ) and superior colliculus (SC, AP: -6.80 to $-7.30 \mathrm{~mm}$, area: $0.3 \times 10^{6} \mu \mathrm{m}^{2}$ ). The results are expressed as neuron density (number of positive cells in $0.1 \mathrm{~mm}^{2}$ ).

\section{Statistical Analysis}

The percentages of open arm entries $(100 \times$ open/total entries) and of time spent on the open arms $(100 \times$ open/ open + enclosed) were calculated for each rat. The behavioral and Fos data were analyzed by $t$-test or one-way analysis of variance (ANOVA) followed by the Duncan test for multiple comparisons.

\section{RESULTS}

\section{Behavioral Experiments}

A diagram showing representative injection sites can be seen in Figure 1.

Experiment 1: CCK-8s decreased the percentage of time spent in open arms $(\mathrm{F}(2,29)=5.51, p<0.05$, Figure 2). No effect was found in the number of enclosed arm entries $(F(2,29)=0.65, N S)$ or percentage of entries onto open arms
$(\mathrm{F}(2.29)=2.01, \mathrm{NS})$. Animals that received saline or CCK-8s $1 \mu \mathrm{g}$ into the superior colliculus did not differ in any parameter $(p>0.05$, Figure 3).

Experiment 2: CCK-8s caused a significant decrease in percentage of time spent in open arms $(\mathrm{F}(3,48)=3.48$, $p<0.05$, Duncan, $p<0.05$, Figure 4). This effect was prevented by pretreatment with PD 135,158 (Duncan, $p>0.05)$. No significant difference was found in the number of enclosed arm entries $(\mathrm{F}(3,48)=0.96, \mathrm{NS})$ or percentage of open arm entries $(\mathrm{F}(3,48)=2.29$, NS).

Experiment 3: CCK-8s decreased the percentage of time spent in open arm $(F(5,71)=2.94, p=0.018$, Duncan, $p<0.05$, Figure 5). This effect was not prevented by pretreatment with any dose of lorglumide (Duncan, $p<0.05)$. No difference was found in the number of enclosed arm entries $(F(5,71)=0.98$, NS) or percentage of open arm entries $(F(5,71)=1.08, \mathrm{NS})$.

\section{Fos Immunohistochemistry}

Experiment 1: Results can be seen in Table 1 and in Figure 6. CCK-8s induced a significant increase in FIr cells, as compared to saline and naive animals, in the MeAmyg $(\mathrm{F}(2,8)=16.4, p<0.005$, Duncan, $p<0.05$, Table 1), LSd $(\mathrm{F}(2,8)=11.8, p<0.01$, Duncan, $p<0.05)$, LSv $(\mathrm{F}(2,8)=$ $22.2, p<0.001$, Duncan, $p<0.05)$, PVNm $(\mathrm{F}(2,8)=5.11$, $p<0.05$, Duncan, $p<0.05)$, dlPAG $(\mathrm{F}(2,8)=15.7, p<0.01$, Duncan, $p<0.05)$, dmPAG $(\mathrm{F}(2,8)=6.4, p<0.05$, Duncan, $p<0.05)$, lPAG $(\mathrm{F}(2,8)=140.1, p<0.001$, Duncan, $p<0.05)$, DRN $(\mathrm{F}(2,8)=279.8, p<0.001$, Duncan, $p<0.01)$, MRN $(\mathrm{F}(2,8)=17.4, p<0.001$, Duncan, $p<0.05)$, and superior colliculus $(\mathrm{F}(2,8)=21.5, p<0.05$, Duncan, $p<0.05)$. In addition, significant differences between CCK-8s and naive groups were found in the frontal cortex $(\mathrm{F}(2,8)=8.0$,

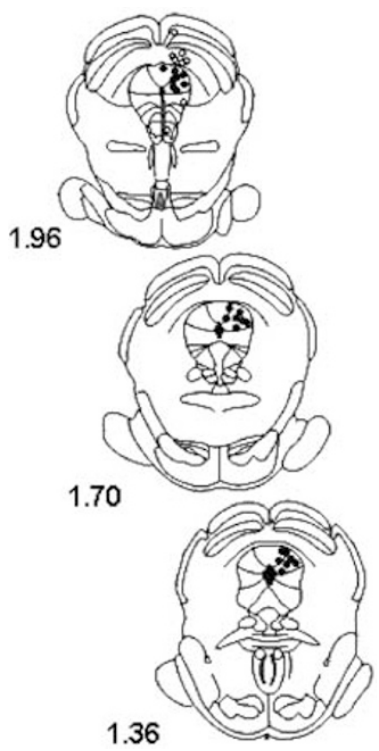

Figure I Histological localization of representative injection sites in diagrams of rat midbrain (modified from Paxinos and Watson, 1997). Solid circles indicate injection sites into the dPAG whereas open circles show sites outside this structure. Owing to superimposition the number of points is smaller than the number of injection sites. 

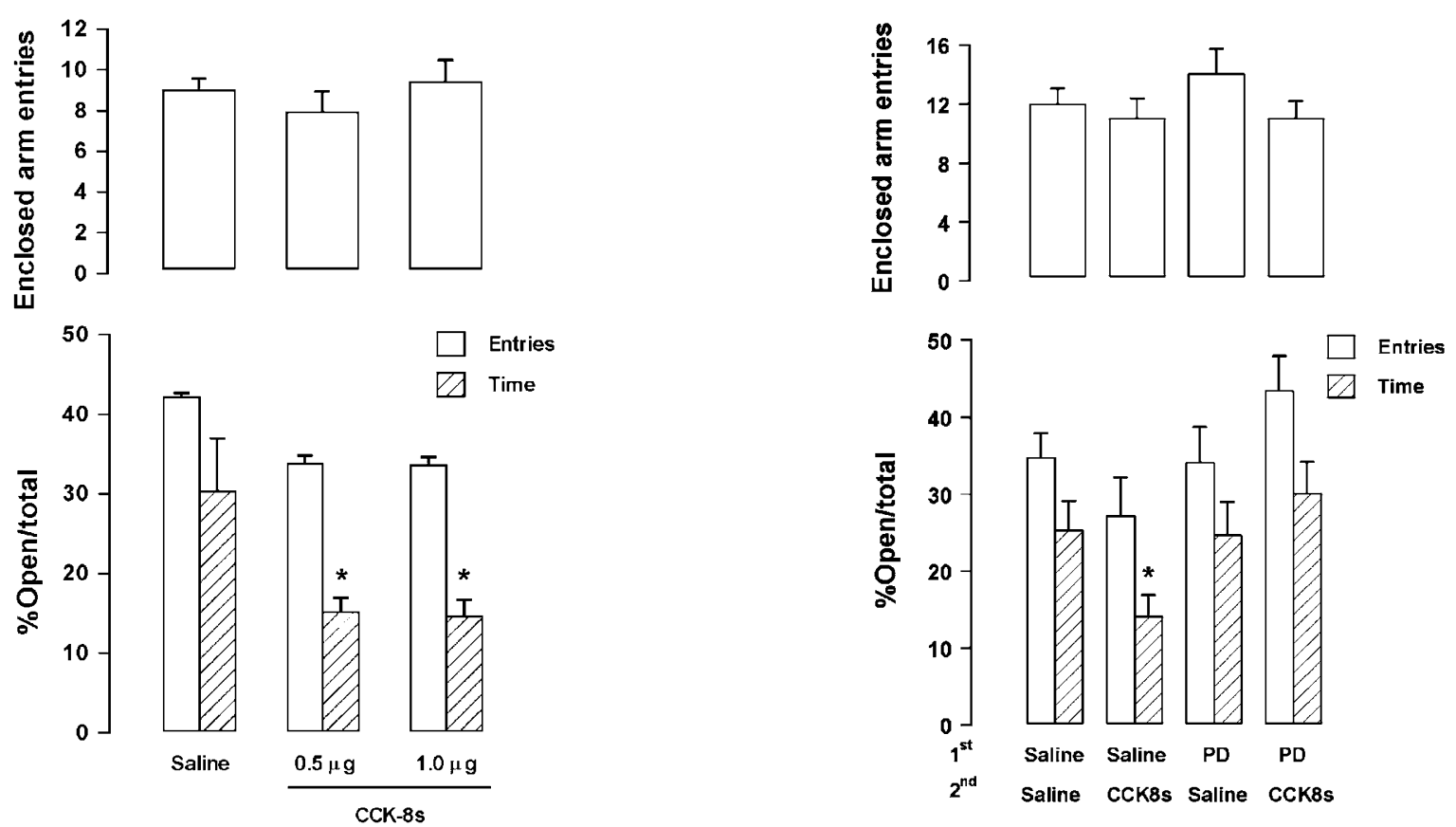

Figure 2 Effect in the EPM of CCK-8s $(0.5-\mid \mu \mathrm{g})$ or saline $(0.5 \mu \mathrm{l})$ microinjected into the dorsal periaqueductal gray of rats $(n=|1-| 5 \mid$ group). The lower panel shows the mean (+SEM) percentage of entries (open bars) and time spent (hatched bars) in open arms. The upper panel shows the mean (+SEM) number of entries into enclosed arms. *Significant differences from saline group (ANOVA followed by the Duncan test, $p<0.05)$.
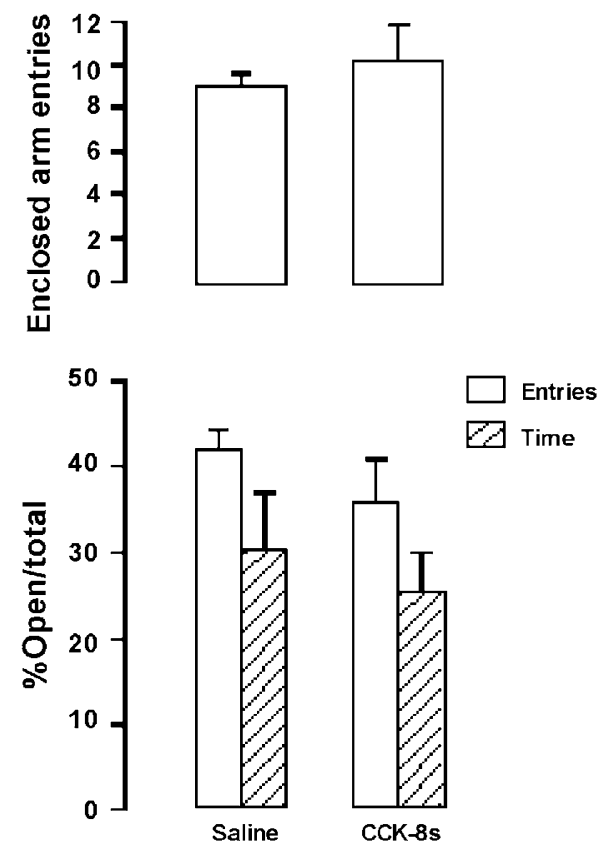

Figure 3 Effect in the EPM of CCK-8s $(\mid \mu g, n=4)$ or saline $(0.5 \mu \mid$ $n=9)$ microinjected into the superior colliculus of rats. The lower panel shows the mean ( + SEM) percentage of entries (open bars) and time spent (hatched bars) in open arms. There is no difference between groups. Further specifications as in Figure 2.

$p<0.05$, Duncan, $p<0.05)$, cingulated cortex $(\mathrm{F}(2,8)=5.6$, $p<0.05$, Duncan, $p<0.05)$, piriform cortex $(\mathrm{F}(2,8)=$ $4.1, p<0.05$, Duncan, $p<0.05)$, blAmyg $(\mathrm{F}(2,8)=4.9$,

Figure 4 Effect in the EPM of PD 135,I58 (PD, 0.I $\mu \mathrm{g}$ ) on the anxiogenic effect induced by CCK-8s $(\mid \mu g)$ microinjected into the dorsal periaqueductal gray of rats $(n=||-\mid 5 /$ group). Animals received a first microinjection of either PD or saline $(0.5 \mu \mathrm{l})$ followed, 5 min later, by a second microinjection of saline or CCK-8s. *Significant difference from saline-saline group (ANOVA followed by the Duncan test, $p<0.05$ ). Further specifications as in Figure 2.

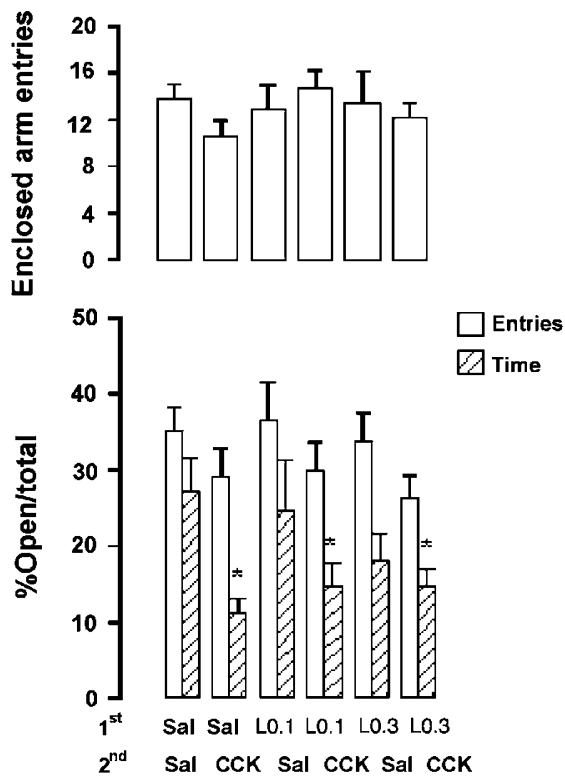

Figure 5 Effect in the EPM of lorglumide $(L, 0.1$ or $0.3 \mu \mathrm{g})$ on the anxiogenic effect induced by CCK-8s $(\mid \mu \mathrm{g})$ microinjected into the dorsal periaqueductal gray of rats $(n=7-17 /$ group). Animals received a first microinjection of either lorglumide or saline (Sal, $0.5 \mu \mathrm{l}$ ) followed, $5 \mathrm{~min}$ later, by a second microinjection of saline or CCK-8s. *Significant difference from saline-saline group (ANOVA followed by the Duncan test, $p<0.05$ ). Further specifications as in Figure 2.

$p<0.05$, Duncan, $p<0.05)$, CA1 $(\mathrm{F}(2,8)=14.3, p<0.005$, Duncan, $p<0.05)$, LSi $(\mathrm{F}(2,8)=10.0, p<0.01$, Duncan, $p<0.05)$, AntH $(\mathrm{F}(2,8)=8.4, p<0.05$, Duncan, $p<0.05)$, 
Table I Mean ( \pm SEM) Number of Flr-Positive Neurons/ $0.1 \mathrm{~mm}^{2}$ in Brain Regions After Injection into the dPAG of Saline $(0.5 \mu \mathrm{l})$ or CCK-8s $(\mathrm{I} \mu \mathrm{g})$

\begin{tabular}{|c|c|c|c|}
\hline & Naive $(n=3)$ & Saline $(n=4)$ & CCK-8s $(n=4)$ \\
\hline Frontal ctx & $2.9 \pm 0.5$ & $13.9 \pm 8.2$ & $21.2 \pm 2.2 *$ \\
\hline Cingulate ctx & $8.5 \pm 3.4$ & $35.4 \pm 13.0$ & $62.2 \pm 11.1 *$ \\
\hline Piriform ctx & $4.7 \pm 3.2$ & $45.3 \pm 16.9 *$ & $46.9 \pm 3.8^{*}$ \\
\hline LSI & $2.8 \pm 1.2$ & $17.4 \pm 1.8^{*}$ & $16.8 \pm 3.3^{*}$ \\
\hline LSd & $2.4 \pm 0.5$ & $12.6 \pm 2.6$ & $20.7 \pm 3.0^{*,+}$ \\
\hline LSV & $3.8 \pm 1.4$ & $27.5 \pm 4.7$ & $46.5 \pm 4.8^{*,+}$ \\
\hline BNSTm & $1.9 \pm 0.6$ & $3.8 \pm 1.0$ & $3.5 \pm 0.7$ \\
\hline BNSTV & $1.3 \pm 0.1$ & $2.2 \pm 0.6$ & $2.4 \pm 0.5$ \\
\hline CAI & $1.2 \pm 0.9$ & $6.4 \pm 0.9 *$ & $4.5 \pm 0.01 *$ \\
\hline CA2 & $0.5 \pm 0.3$ & $4.3 \pm 0.7$ & $3.2 \pm 1.3$ \\
\hline CA3 & $1.4 \pm 0.6$ & $2.8 \pm 1.1$ & $1.2 \pm 0.7$ \\
\hline BIAmyg & $2.1 \pm 0.4$ & $4.5 \pm 0.8$ & $5.9 \pm 1.2^{*}$ \\
\hline CeAmyg & $4.9 \pm 1.5$ & $3.8 \pm 0.9$ & $6.8 \pm 2.5$ \\
\hline MeAmyg & $0.7 \pm 0.3$ & $3.8 \pm 0.7$ & $\mid 8.1 \pm 3.5^{*^{+}}$ \\
\hline AntH & $1.9 \pm 0.6$ & $10.3 \pm 2.4 *$ & $11.6 \pm 1.1 *$ \\
\hline $\mathrm{DmH}$ & $5.4 \pm 0.7$ & $14.9 \pm 3.2$ & $22.4 \pm 3.0 *$ \\
\hline $\mathrm{LH}$ & $5.6 \pm 1.0$ & $22.0 \pm 4.4 *$ & $32.6 \pm 3.0 *$ \\
\hline PVNm & $3.9 \pm 2.4$ & $11.7 \pm 3.5$ & $36.5 \pm 11.1^{*,+}$ \\
\hline PVNp & $9.9 \pm 1.8$ & $33.1 \pm 5.0$ & $71.7 \pm 19.8 *$ \\
\hline PVT & $27.2 \pm 11.3$ & $36.3 \pm 8.3$ & $58.5 \pm 5.0 *$ \\
\hline DIPAG & $5.8 \pm 2.1$ & $9.7 \pm 3.1$ & $28.4 \pm 2.9^{*,+}$ \\
\hline DmPAG & $7.6 \pm 3.5$ & $9.8 \pm 3.5$ & $27.2 \pm 5.2^{*,+}$ \\
\hline LPAG & $8.4 \pm 1.3$ & $12.5 \pm 1.4$ & $34.6 \pm 3.0^{*,+}$ \\
\hline SC & $10.2 \pm 0.2$ & $18.1 \pm 2.1$ & $40.8 \pm 3.1^{*,+}$ \\
\hline MRN & $2.4 \pm 0.2$ & $11.7 \pm 2.1 *$ & $24.9 \pm 3.6^{*,+}$ \\
\hline DRN & $2.7 \pm 1.2$ & $22.1 \pm 1.2 *$ & $58.4 \pm 2.1^{*,+}$ \\
\hline
\end{tabular}

Animals ( $n=3-4)$ were killed $2 \mathrm{~h}$ after injection. Naive animals remained in their home cage for this period. *Significant difference from naive animals, ${ }^{+}$significant difference from saline-treated animals (ANOVA followed by the Duncan test). $\mathrm{Ctx}=$ cortex, $\mathrm{LSi}=$ lateral septal nucleus, intermediate, $\mathrm{LSd}=$ lateral septal nucleus, dorsal, $\mathrm{LSv}=$ lateral septal nucleus, ventral, BNSTm $=$ medial division of the bed nucleus of the stria terminalis, BNSTV = lateral division of the bed nucleus of the stria terminalis, ventral part, BIAmyg = basolateral amygdala, CeAmyg = central nucleus of the amygdala, MeAmyg = medial amygdala, CAI, $\mathrm{CA} 2$, and $\mathrm{CA} 3$ regions of the hippocampus, $\mathrm{AntH}=$ anterior hypothalamus, $\mathrm{DmH}=$ dorsomedial nucleus of the hypothalamus, $\mathrm{LH}=$ lateral hypothalamus, $\mathrm{PVNm}=$ paraventricular nucleus of the hypothalamus, magnocellular, $\mathrm{PVNp}=$ paraventricular nucleus of the hypothalamus, parvocellular, $\mathrm{PVT}=$ paraventricular nucleus of the thalamus, $\mathrm{dPAG}=$ dorsolateral periaqueductal gray, dmPAG = dorsomedial PAG, IPAG = lateral PAG, $\mathrm{SC}=$ superior colliculus, $\mathrm{MRN}=$ median raphe nucleus, $\mathrm{DRN}=$ dorsal raphe nucleus.

$\mathrm{DmH} \quad(\mathrm{F}(2,8)=8.35, \quad p<0.05, \quad$ Duncan, $p<0.05), \quad \mathrm{LH}$ $(\mathrm{F}(2,8)=14.2, p<0.05$, Duncan, $p<0.05)$, PVNp $(\mathrm{F}(2,8)=$ 5.5, $p<0.05$, Duncan, $p<0.05)$, and PVT $(\mathrm{F}(2,8)=3.96$, $p<0.05$, Duncan, $p<0.05)$. In the piriform cortex, CA1, LSi, AntH, and LH the saline group was also different from naive animals (Duncan, $p<0.05$ ).

Experiment 2: Results are in Table 2. Rats treated with saline-CCK-8s had greater FIr cells, as compared to saline-saline and $\mathrm{PD} 135,158$ treated animals, in the $\mathrm{LH}(\mathrm{F}(3,8)=2.80, p=0.10$, Duncan, $p<0.05)$, PVT

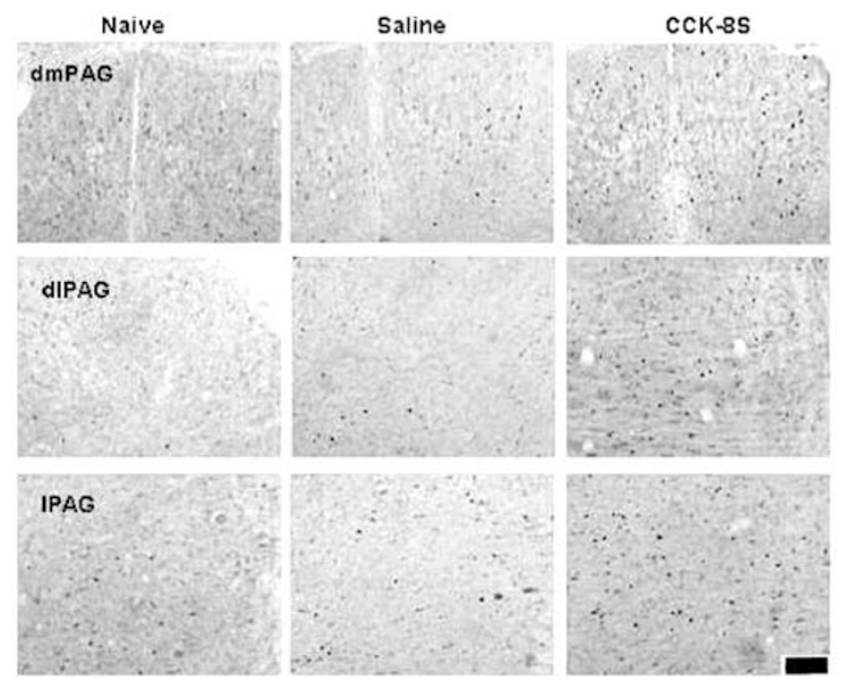

Figure 6 Photomicrographs showing Fos immunoreactive neurons in the dorsolateral $(\mathrm{dl})$, dorsomedial $(\mathrm{dm})$, or lateral $(\mathrm{I})$ periaqueductal gray (PAG) of rats that received microinjections into the dPAG of saline $(0.5 \mu \mathrm{l})$ or CCK-8s $(\mid \mu \mathrm{g})$. Naive rat was left undisturbed in their home. Bar $=100 \mu \mathrm{m}$

$(\mathrm{F}(3,8)=7.28, p<0.05$, Duncan, $p<0.05)$, dlPAG $(\mathrm{F}(3,8)=$ 9.80, $p<0.01$, Duncan, $p<0.05)$, SC $(\mathrm{F}(3,8)=11.9, p<0.01$, Duncan, $p<0.05)$, and $\mathrm{DRN} \quad(\mathrm{F}(3,8)=5.09, p<0.05$, Duncan, $p<0.05)$. Significant differences, as compared to saline-saline or PD 135,158 groups only, were found after saline-CCK-8s injection in, respectively, the IPAG $(\mathrm{F}(3,8)=3.6, p=0.06$, Duncan, $p<0.05)$ and $\operatorname{MRN}(\mathrm{F}(3,8)=$ 5.53, $p<0.05$, Duncan, $p<0.05)$ or the BNSTm $(\mathrm{F}(3,8)=2.90, p=0.10$, Duncan, $p<0.05)$, LSd $(\mathrm{F}(3,8)=$ .3.99, $p=0.052$, Duncan, $p<0.05)$, and PVNp $(\mathrm{F}(3,8)=4.99$, $p<0.05$, Duncan, $p<0.05$ ).

\section{DISCUSSION}

The EPM is a widely employed animal model of anxiety (File, 1992). Rodents usually avoid the open arms of this apparatus, most likely because they cannot engage in thigmotaxic behavior (Treit et al, 1993). CCK-8s decreased the percentage of time spent in the open arms, without changing the number of enclosed arm entries. The results suggest an anxiogenic effect (File, 1992) and are similar to those previously described by Guimarães et al (1992). Strengthening the role of the $\mathrm{dPAG}$ in this result, injections of CCK-8s into the superior colliculus had no effect.

The two doses of CCK-8s employed had similar effects, suggesting that a maximum effect in the dPAG was reached. This neuropeptide acts as a full agonist at both CCKreceptor subtypes (Fink et al, 1998). The anxiogenic effect of CCK-8s was completely prevented by pretreatment with PD 135,158 , a CCK-2 receptor antagonist. Similar effects have been reported after i.c.v. administration of CCK-8s (Hernandez-Gomez et al, 2002). CCK-2 receptors are abundantly expressed in the brain and are present in the PAG (Mercer et al, 1996). Pharmacological studies suggest that they modulate anxiety reactions (Rehfeld, 2000). For example, CCK-4, a CCK-2 full agonist, induces panic symptoms in 
Table 2 Effects of Pretreatment with PD 135 I 58 (PD, $0.1 \mu \mathrm{g} /$ $0.5 \mu \mathrm{l})$ on Flr Expression Induced by CCK-8S ( I $\mu \mathrm{g})$ Injection into the $\mathrm{dPAG}$

\begin{tabular}{|c|c|c|c|c|}
\hline & $\begin{array}{c}\text { Saline+saline } \\
\quad(n=3)\end{array}$ & $\begin{array}{c}\text { Saline+CCK- } \\
8 \mathrm{~s}(n=3)\end{array}$ & $\begin{array}{l}\text { PD+saline } \\
(n=2)\end{array}$ & $\begin{array}{c}\text { PD+CCK-8s } \\
(n=4)\end{array}$ \\
\hline Frontal ctx & $19.4 \pm 1.2$ & $25.7 \pm 4.3$ & $13.4 \pm 5.8$ & $15.3 \pm 5.9$ \\
\hline Cingulate ctx & $12.9 \pm 3.3$ & $20.8 \pm 6.2$ & $8.19 \pm 2.4$ & $9.2 \pm 3.8$ \\
\hline Piriform ctx & $12.9 \pm 4.9$ & $13.8 \pm 2.8$ & $15.3 \pm 3.4$ & $9.2 \pm 1.8$ \\
\hline Lsi & $3.9 \pm 1.0$ & $4.9 \pm 1.5$ & $3.5 \pm 1.2$ & $3.9 \pm 1.5$ \\
\hline LSd & $6.9 \pm 1.9$ & $14.6 \pm 4.0^{+}$ & $7.1 \pm 0.8$ & $3.9 \pm 1.1$ \\
\hline LSv & $23.9 \pm 3.7$ & $23.7 \pm 2.5$ & $24.5 \pm 8.1$ & $23.5 \pm 5.4$ \\
\hline BNSTm & $7.6 \pm 1.6$ & $13.1 \pm 3.7^{+}$ & $10.1 \pm 0.2$ & $4.9 \pm 1.1$ \\
\hline BNSTV & $4.2 \pm 1.3$ & $6.5 \pm 1.9$ & $6.1 \pm 3.6$ & $4.4 \pm 1.2$ \\
\hline CAI & $2.2 \pm 0.8$ & $7.2 \pm 3.5$ & $4.6 \pm 3.8$ & $2.6 \pm 0.6$ \\
\hline CA2 & $3.5 \pm 1.1$ & $6.6 \pm 2.7$ & $4.6 \pm 1.2$ & $4.9 \pm 1.4$ \\
\hline CA3 & $6.2 \pm 1.0$ & $9.4 \pm 2.6$ & $3.5 \pm 2.3$ & $4.5 \pm 1.1$ \\
\hline BIAmyg & $4.4 \pm 0.8$ & $6.7 \pm 0.3$ & $4.5 \pm 0.7$ & $4.8 \pm 1.3$ \\
\hline CeAmyg & $7.7 \pm 0.7$ & $15.5 \pm 3.7$ & $8.1 \pm 5.1$ & $16.7 \pm 2.5$ \\
\hline MeAmyg & $4.4 \pm 1.1$ & $6.6 \pm 1.4$ & $4.1 \pm 0.5$ & $7.3 \pm 1.3$ \\
\hline AntH & $12.1 \pm 1.6$ & $15.5 \pm 3.3$ & $9.5 \pm 2.7$ & $9.9 \pm 3.4$ \\
\hline $\mathrm{DMH}$ & $17.7 \pm 1.1$ & $20.9 \pm 2.6$ & $20.2 \pm 3.4$ & $22.9 \pm 3.8$ \\
\hline $\mathrm{LH}$ & $14.7 \pm 1.3$ & $24.2 \pm 0.7^{*,+}$ & $19.9 \pm 1.1$ & $14.5 \pm 3.8$ \\
\hline PVNm & $8.2 \pm 0.7$ & $18.7 \pm 7.8$ & $12.3 \pm 0.6$ & $9.9 \pm 3.1$ \\
\hline PVNp & $33.8 \pm 4.3$ & $42.6 \pm 2.6^{+}$ & $30.8 \pm 7.2$ & $19.2 \pm 4.7$ \\
\hline PVT & $26.7 \pm 9.3$ & $73.8 \pm 3.8^{*,+}$ & $45.8 \pm 4.7$ & $32.1 \pm 8.5$ \\
\hline DIPAG & $11.8 \pm 3.7$ & $31.1 \pm 0.6^{*,+}$ & $20.9 \pm 1.8$ & $18.9 \pm 2.3$ \\
\hline DmPAG & $10 \pm 0.8$ & $23.0 \pm 3.3$ & $17.4 \pm 1.0$ & $17.9 \pm 4.8$ \\
\hline LPAG & $11.8 \pm 2.3$ & $26.4 \pm 4.9^{*,+}$ & $18.4 \pm 3.1$ & $20.2 \pm 1.8$ \\
\hline SC & $8.6 \pm 3.7$ & $38.2 \pm 5.2^{*,+}$ & $8.8 \pm 7.8$ & $9.1 \pm 2.3$ \\
\hline MRN & $7.6 \pm 0.8$ & $15.0 \pm 1.9 *$ & $8.7 \pm 0.6$ & $11.8 \pm 1.3$ \\
\hline DRN & $8.2 \pm 1.4$ & $26.2 \pm 4.4^{*,+}$ & $6.0 \pm 1.0$ & $12.5 \pm 4.3$ \\
\hline
\end{tabular}

Animals $(n=2-4)$ were killed $2 \mathrm{~h}$ after the last injection. Flr was expressed as the mean $\left( \pm\right.$ SEM) number of positive cells $/ 0.1 \mathrm{~mm}^{2}$. *Significant difference from saline-saline group, ${ }^{+}$significant difference from PD-CCK-8s group (ANOVA followed by Duncan test). Further specifications as in Table I.

humans and anxiety-like behavior in rodents (Rehfeld, 2000).

Lorglumide pretreatment did not prevent the anxiogenic effect of CCK-8s. This drug is a selective and potent CCK-1 receptor antagonist (Herranz, 2003). The doses used were similar or higher than the one used with PD 135,158. However, pharmacological studies using systemic or i.c.v. administration of these compounds show that the active doses to antagonize CCK-1 or CCK-2 receptors, respectively, are similar (Felicio et al, 2001; Suh et al, 1995). Also, a lower dose of lorglumide was able to prevent CCK-1mediated effect of a CCK agonist on tail flick responses after i.c.v. administration (Suh et al, 1996). Therefore, CCK-1 receptors are probably not involved in the anxiogenic effect of intra-dPAG administration of CCK-8s.

PD 135,158 administered alone had no effect in the EPM. This suggests that CCK-2-mediated neurotransmission in the dPAG does not play a significant role on anxiety induced by EPM exposure. This does not exclude the involvement of these receptors in anxiety modulation under more stressful conditions. For example, CCK-2 antagonism was able to decrease the anxiogenic effect of a cat exposure in rats tested in the EPM (Adamec et al, 1997). This could be related to the increased brain expression of CCK (Del Bel and Guimarães, 1997; Pavlasevic et al, 1993; Rosen et al, 1992) and CCK-2 mRNA (Wang et al, 2003) found after exposure to stressful conditions. It was proposed that, under these conditions, CCK could sensitize the PAG, facilitating depolarization of PAG neurons by glutamate excitatory inputs (Behbehani, 1995). Administration of CCK-8s into the dPAG induced Fos expression in several brain regions related to defensive behaviors (for a review, see Sewards and Sewards, 2002). However, the significant differences between saline-treated and naive animals showed that the injection procedure was also able to activate several of these regions. More consistent effects were found in midbrain structures such as the PAG itself, raphe nuclei, and superior colliculus, and in the lateral septal nuclei, medial amygdala, medial hypothalamus, paraventricular hypothalamus, and the paraventricular thalamic nucleus. All these areas are connected, directly or indirectly, to the dPAG (Shipley et al, 1991; Beitz, 1995). They are proposed to be part of a fear and powerdominance neural representation system that is activated by several threatening or stressful stimuli (Silveira et al, 1994; Canteras and Goto, 1999; Lino-de-Oliveira et al, 2001; Dilenberg and McGregor, 2001; Sewards and Sewards, 2002). In addition, the paraventricular thalamic nucleus has recently been implicated in the regulation of hypothalamic-pituitary-adrenal function through a CCK-mediated pathway recruited by chronic stress (Bhatnagar et al, 2000).

Similar to the behavioral data, pretreatment with PD 135,158 prevented the effect of CCK-8s on Fos expression. This reinforces the role of CCK- 2 receptors on the effects induced by CCK-8s administration into the dPAG.

In conclusion, our data indicate that CCK-8s, acting on CCK-2 receptors, can modulate anxiety-like behaviors in the dPAG.

\section{ACKNOWLEDGEMENTS}

We thank JC de Aguiar and ET Gomes for the excellent technical support. Research supported by grants from FAPESP (98/10639-7, 02/13197-2), CAPES, and CNPq.

\section{REFERENCES}

Adamec RE, Shallow T, Budgell J (1997). Blockade of CCK(B), but not $\operatorname{CCK}(\mathrm{A})$, receptors before and after the stress of predator exposure prevents lasting increases in anxiety-like behavior: implications for anxiety associated with posttraumatic stress disorder. Behav Neurosci 111: 435-449.

Behbehani MM (1995). Functional characteristics of the midbrain periaqueductal gray. Prog Neurobiol 46: 575-605.

Beitz AJ (1995). Periaqueductal gray. In: Paxinos G (ed). The Rat Nervous System 2nd edn Academic Press: San Diego. pp 173-182.

Bhatnagar S, Viau V, Chu A, Soriano L, Meijer OC, Dallman MF (2000). A cholecystokinin-mediated pathway to the paraventricular thalamus is recruited in chronically stressed rats and regulates hypothalamic-pituitary-adrenal function. J Neurosci 20: 5564-5573.

Bradwejn J, Koszycki D, Cöuetoux Du Tertre A, Bourin M, Palmour R, Ervin F (1992). The cholecystokinin hypothesis of 
panic and anxiety disorders: a review. J Psychopharmacol 6: 345-351.

Bradwejn J, Koszycki D, Cöuetoux Du Tertre A, Van Megen H, Den Boer J, Westenberg H (1994). The panicogenic effects of cholecystokinin-tetrapeptide are antagonized by L-365260, a central cholecystokinin receptor antagonist, in patients with panic disorder. Arch Gen Psychiatry 51: 486-493.

Canteras NS, Goto M (1999). Fos-like immunoreactivity in the periaqueductal gray of rats exposed to a natural predator. NeuroReport 10: 413-418.

Costall B, Domeney AM, Hughes J, Kelly ME, Naylor RJ, Woodruff GN (1991). Anxiolytic effects of CCKB antagonists. Neuropeptides 19(Suppl): 65-73.

De Belleroche J, Bandopadhyay R, King A, Malcolm ADBK, Premi BP, Rashid A (1990). Regional distribution of cholecystokinin messenger RNA in rat brain during development: quantification and correlation with cholecystokinin immunoreactivity. Neuropeptides 15: 201-212.

De Oliveira RW, Del Bel EA, Guimarães FS (2000). Behavioural and c-fos expression changes induced by nitric oxide donors microinjected into the dorsal periaqueductal gray. Brain Res Bull 51: 457-464.

Del Bel EA, Guimarães FS (1997). Social isolation increases cholecystokinin mRNA expression in the central nervous system of rats. NeuroReport 8: 3597-3600.

Dilenberg RA, McGregor IS (2001). Defensive behavior in rats towards predatory odors: a review. Neurosci Biobehav Rev 25: 597-609.

Felicio LF, Mazzini BK, Cacheiro RG, Cruz TN, Florio JC, Nasello AG (2001). Stimulation of either cholecystokinin receptor subtype reduces while antagonists potentiate or sensitise a morphine-induced excitatory response. Peptides 22: 1299-1304.

File SE (1992). Behavioural detection of anxiolytic action. In: Elliott JM, Heal DJ, Marsden CA (eds). Experimental Approaches to Anxiety and Depression. John Wiley \& Sons: New York. pp 25-44.

Fink H, Rex A, Voits M, Voigt JP (1998). Major biological actions of CCK - a critical evaluation of research findings. Exp Brain Res 123: 77-83.

Griebel G, Perrault G, Sanger DJ (1997). CCK receptor antagonists in animal models of anxiety: comparison between exploration tests, conflict procedures and a model based on defensive behaviors. Behav Pharmacol 8: 549-560.

Guimarães FS, Carobrez AP, De Aguiar JC, Graeff FG (1991). Anxiolytic effect in the elevated plus-maze of the NMDA receptor antagonist AP7 microinjected into the dorsal periaqueductal grey. Psychopharmacology 103: 91-94.

Guimarães FS, Russo AS, De Aguiar JC, Ballejo G, Graeff FG (1992). Anxiogenic-like effect of CCK-8 micro-injected into the dorsal periaqueductal grey of rats in the elevated plus maze. In: Dourish CT, Cooper SJ, Iversen SD, Iversen LL (eds). Multiple Cholecystokinin Receptors in the CNS. Oxford Science Publication: Oxford. pp 149-154.

Hernandez-Gomez AM, Aguilar-Roblero R, Pérez de La Mora M (2002). Role of cholecystokinin-A and cholecystokinin-B receptors in anxiety. Amino Acids 23: 283-290.

Herranz R (2003). Cholecystokinin antagonists: pharmacological and therapeutic potential. Med Res Rev 23: 559-605.

Lino-de-Oliveira C, Sales AJ, Del Bel EA, Silveira MCL, Guimarães FS (2001). Effects of acute and chronic fluoxetine treatments on restraint stress-induced Fos expression. Brain Res Bull 55: 747-754.

Liu H, Chandler S, Beitz AJ, Shipley MT, Behbehani MM (1994). Characterization of the effect of cholecystokinin (CCK) on neurons in the periaqueductal gray of the rat: immunocytochemical and in vivo and in vitro electrophysiological studies. Brain Res 642: 83-94.

Lovick TA (2000). Panic disorder - a malfunction of multiple transmitter control systems within the midbrain periaqueductal gray matter? Neuroscientist 6: 48-59.

Mercer LD, Beart PM, Horne MK, Finkelstein DJ, Carrive P, Paxinos G (1996). On the distribution of cholecystokinin B receptors in monkey brain. Brain Res 738: 313-318.

Morgan JI, Curran T (1995). Proto-oncogenes: beyond second messengers. In: Bloom FE, Kupfer DJ (eds). Psychopharmacology: The Fourth Generation of Progress. Raven Press: New York. pp 631-642.

Pavlasevic S, Bednar I, Qureshi GA, Södersten P (1993). Brain cholecystokinin tetrapeptide levels are increased in a rat model of anxiety. NeuroReport 5: 225-228.

Paxinos G, Watson C (1997). The Rat Brain in Stereotaxic Coordinates 3th edn. Academic Press: New York.

Rehfeld JF (2000). Cholecystokinin and panic disorder-three unsettled questions. Reg Peptides 93: 79-83.

Rosen A, Brodin K, Eneroth P, Brodin E (1992). Short-term restraint stress and s.c. saline injection alter the tissue levels of substance $\mathrm{P}$ and cholecystokinin in the periaqueductal grey and limbic regions of rat brain. Acta Physiol Scand 148: 341-348.

Russo AS, Guimarães FS, De Aguiar JC, Graeff FG (1993). Role of benzodiazepine receptors located in the dorsal periaqueductal grey of rats in anxiety. Psychopharmacology 110: 198-202.

Sewards TV, Sewards MA (2002). Fear and power-dominance motivation neural representation and pathways mediating sensory and mnemonic inputs and outputs to premotor structures. Neurosci Biobehav Rev 26: 553-579.

Shipley MT, Ennis M, Rizvi TA, Behbehani MM (1991). Topographical specificity of forebrain inputs to the midbrain periaqueductal gray: evidence for discrete longitudinally organized input columns. In: Depaulis A, Bandler $\mathrm{R}$ (eds). The Midbrain Periaqueductal Gray Matter: Functional, Anatomical and Neurochemical Organization. Plenum Press: New York. pp 417-448.

Silveira M.CL, Graeff FG, Sandner G (1994). Regional distribution of Fos-like immunoreactivity in the rat brain after exposure to fear-inducing stimuli. Braz J Med Biol Res 27: 1077-1081.

Singewald N, Sharp T (2000). Neuroanatomical targets of anxiogenic drugs in the hindbrain as revealed by Fos immunocytochemistry. Neuroscience 98: 759-770.

Suh HW, Kim YH, Choi YS, Song DK (1995). Involvement of different subtypes of cholecystokinin receptors in opióide antinociception in the mouse. Peptides 16: 229-234.

Suh HW, Song DK, Kwon SH, Kim KW, Min BH, Kim YH (1996). Involvement of supraspinal and spinal CCK receptors in the modulation of antinociception induced by cold water swimming stress in the mouse. Neuropeptides 30: 379-384.

Treit D, Menard J, Royan C (1993). Anxiogenic stimuli in the elevated plus-maze. Pharmacol Biochem Behav 44: 463-469.

Wang H, Zhu YZ, Farrok JM, Moochhala S, Teo AL, Lee LKH et al (2003). Genetic variations in CCK2 receptor in PVG Hooded and Sprague-Dawley rats and its mRNA expression on cat exposure. Behav Neurosci 117: 385-390. 